\title{
Application of Some Management Strategies on Leaf Spot and Fruit Rot Diseases of Watermelon (Citrullus Lanatus) in South Eastern Nigeria
}

Asuquo, Aniebiet Austin, *Opara Emma Umunna

Department of Plant Health Management, Michael Okpara University of Agriculture, Umudike

\begin{abstract}
A field trial was conducted at the Research Farms of Michael Okpara University of Agriculture, Umudike, South Eastern Nigeria to assess the potential of leaves, seeds, barks and roots of Azadirachta indica and Moringa oleifera in the control of bacterial spot and fruit rot diseases of watermelon (Citrullus lanatus), in a Randomized Complete Block Design (RCBD) experiment. Results obtained showed that all the plants parts assessed reduced disease incidence and severity drastically at 5\% probability when compared with the control. Extracts of $A$. indica seed had the best performance at 12 weeks after planting on vine length $(140 \mathrm{~cm})$, number of branches $(8.00)$, number of leaves (49.00), and number of fruits (16.00) and compared favourably with synthetic pestic ide (streptomycin) on fruit weight at harvest $(4.96 \mathrm{~kg})$ and in reducing incidence of the bacterial spot $(61.27 \%)$ and fruit rot $(35.51 \%)$ as well as severity of the spots (2.64) and rot (3.33) ( $\mathrm{P}=0.05)$. From $\mathrm{t}$ he results obtained it means that the extracts of $A$. indica and $M$. oleifera could serve as a safe and che ap alternative to synthetic pesticides in the management of leaf spot and fruit rot of watermelon.
\end{abstract}

Keywords: Bioe-xtracts, Azadirachta indica, Moringa oleifera, Citrullus lanatus, Bacterial spot, Fruit rot

\section{INTRODUCTION}

Watermelon (Citrullus lanatus (Thunb.) Matsun and Nakai) is a member of the family cucurbitaceae and this family are mostly used as vegetables, a few yield delicious annual fruits and a few are medicinal. Other members of this group include sweet gourd or muskmelon (Cucurbita moschata), pumpkin (C. pepo), Cucumis spp and Momordica spp. It is an important horticultural crop, mostly known for its sweet and juicy fruit, grown in warm climates all over the world (Robinson and DeckerWalters, 1997). In Nigeria, its cultivation which was originally confined to the drier savannah regions of the north, is now gradually gaining ground in the southern parts of the country. However, the largest production of the crop still comes from the northern part of Nigeria where a suitable agro ecology is found (Adekunle et al., 2007). In Africa, watermelon accounted for 5.4\% of the harvested area devoted to vegetable production in 2008 and this contributed to the world water melon production with $4.6 \%$ of 99million tonnes (FAOSTAT, 2008). It is a crop with huge economic importance to man and is mostly cultivated as an under sown intercrop together with cereals or root crops (Ikeorgu,1991; Matanyaire 1998) in the same way as other cucurbits (Ndoro et al., 2007). The fresh fruit is relished by many people across the world because it is known not only to be low in calories but highly nutritious, sweet and thirst-quenching (Mangila et al., 2007). It is also used as a dessert fruit and in the very dry parts of Africa, it is relished by both man and his animals as a source of water. It is a popular cash crop grown by farmers during the dry season due to its high returns in investment, especially those residing near the urban areas. Watermelon contains Vitamin A and C in form of the disease fighting beta-carotene. Potassium is also available in it, which is believed to help in the control of blood pressure and possibly prevent stroke (IITA, 2013).

Watermelons are warm season annuals and are less tolerant to cold than other cucurbits like cucumber and cantaloupe. They require a lot of garden space for good yield and well -drained soils that are rich in organic matter with good water retention capacity (Lawal, 2000; George, 2004). The crop is spaced widely in the farm, though, bush varieties that require less spacing are gradually introduced into cultivation. Watermelon is desired largely as a refreshing source of tasty water and utilizes large amount of moisture to produce juicy flesh (George, 2004). 
Asuquo, Aniebiet Austin \& Opara Emma Umunna "Application of some Management Strategies on Leaf Spot and Fruit Rot Diseases of Watermelon (Citrullus Lanatus) in South Eastern Nigeria"

The numerous uses and potential of watermelon in Nigeria notwithstanding, this all-important crop is not widely cultivated in the southern part of the country including the southeastern agro-ecological zone due to high rainfall and humidity, failure to identify high yielding varieties best adapted or most suitable to the agro - ecological zone and as a result of pest and disease outbreak, crop losses due to pathogens, lack of information on the most appropriate sowing period in order to avert diseases as well as the most appropriate chemical alternative for control of major diseases of the crop.

Diseases play an important role in reducing the quality and quantity of cultivated crops, several diseases attack watermelon (C. lanatus), some of which include angular leaf spot (Pseudomonas syringae $p v$. lachrymans), bacterial fruit blotch/seedling blight (Acidovorax avenae pv. citrulli), bacterial leaf spot (Xanthomonas campestris pv. cucurbitae) and bacterial soft rot (Erwinia caratovora pv. caratovora). Some fungal diseases include Alternaria leaf spot/blight (Alternaria cucumerin), anthracnose (stem, leaf and fruit) (Colletotrichum orbiculare), belly rot (Rhizoctonia solani), black root rot (Theilaviopsis basicola) and Fusarium fruit rot caused by Fusarium equiseti (Martyn et al., 1993; Babadoost, 2002; Roberts and Kucharek, 2006; Amadi et al., 2008).

Control of bacterial diseases of plants has been by the application of synthetic pesticides, however these chemicals are expensive, un-economical and not eco-friendly to the environment. Moreover, the need for repeated application of chemicals to attain desirable level of disease control discourage the extensive adoption of chemical control by most marginal and resource poor farmers. Also, due to the present day public perception on pesticide contamination of foods especially the edible flesh, there is need for development of alternative economical and eco-friendly approaches for plant disease management (Amadioha, 2000). Thus the use of natural plant products provide cheap and readily available pesticides for the resource poor farmers and it ensures qualitative and quantitative production of disease free crops without causing pollution in the environment and harm to non-target organisms. They have been reported to be effective in the control of insect pests (Emosairue and Ukeh, 1996; Emeasor et al., 2005), plant diseases (Tewari and Nayak, 1991; Al-Abed, Qasem and Abu-Blan, 1993; Amadioha, 2004; Opara and Agugo, 2014) and as a bird repellent (Mason and Mathew, 1996).

Recent studies have shown the importance of natural chemicals as a possible source of nonphytotoxic, systemic, and easily biodegradable alternative pesticides (Singh, 1994; Qasem and AbuBlan, 1996, Opara and Wokocha, 2008).

In view of the importance of the crop and the devastating effect that leaf spot and fruit rot can cause on yield, there is a need to assess the occurrence of the diseases in the study area and also determine the alternative plant resource for controlling the diseases in the study area.

\section{MATERIALS AND METHODS}

Experimental Site: The experiment was carried out at the Michael Okpara University of Agriculture Umudike Research farm, Umudike is located at Latitude $5^{\circ} 28^{\prime}$ North and Longitude $7^{\circ} 35^{\prime}$ East and an Altitude of $122 \mathrm{~m}$ above sea level with an annual rainfall of $1916 \mathrm{~mm}$, and relative humidity of $76 \%$ and temperature range of $19-35^{\circ} \mathrm{C}$ (NRCRI, 2010).

Field Preparation: Land was manually cleared and prepared into ridges. Watermelon seeds were sown 2 per hole at a spacing $1 \mathrm{~m} \times 1 \mathrm{~m}$. The experimental design used was Randomized Complete Block Design (RCBD) with three replicates. Each replicate measured $25 \mathrm{~m} \times 10 \mathrm{~m}$ while each plot measured $10 \mathrm{~m} \times 2 \mathrm{~m}$, space between replicates and a plots was $1 \mathrm{~m}$ and $0.5 \mathrm{~m}$ respectively. The total area for the experiment was $25 \mathrm{~m} \times 33 \mathrm{~m}\left(825 \mathrm{~m}^{2}\right)$. Regular weeding was done when necessary using hoe.

Soil Sampling and Analysis: Soil samples were randomly collected from the site at a depth of (0-20 $\mathrm{cm}$ ) before planting, bulked into composite sample and taken to the Soil Science laboratory for analysis to determine the physico- chemical properties of the experimental site. At the laboratory, composite sample was air-dried in a room temperature of $27^{\circ} \mathrm{C}$ for three days, crushed and sieved using $2 \mathrm{~mm}$ aperture. The parameters evaluated include the particle size distribution by hydrometer method (Gee and Bauder, 1986). Soil $\mathrm{pH}$ was determined using Pye Unican model MK2 pH meter in in a 1:2:5 soil/water suspension ratio. Organic carbon was determined by Walkley-Black wet oxidation method (Nelson and Sommers, 1982). Total nitrogen was determined by micro-Kjeldahl distillation technique as described by Breminer and Mulvaney (1982). Available phosphorus was 
Asuquo, Aniebiet Austin \& Opara Emma Umunna "Application of some Management Strategies on Leaf Spot and Fruit Rot Diseases of Watermelon (Citrullus Lanatus) in South Eastern Nigeria"

determined by Bray No.1 method (IITA, 1979). Exchangeable potassium was determined by flame photometer, while cation exchange capacity (CEC) was determined by Amonium acetate saturation method (Roades, 1982).

Source of Seeds: Seeds of watermelon were sourced from the National Seed Council of Nigeria located at National Root Crops Research Institute (NRCRI), Umudike. The variety used in this experiment was Kaolak.

Plant Materials used as Bio-Extracts: Plant samples were sourced locally within the environment of Michael Okpara University of Agriculture, Umudike, National Root Crops Research Institute (NRCRI), Umudike and from the local markets in Abia state. The plants materials used were the leaves, seed, bark and root of Azadirachta indica (neem) and Moringa oleifera. These plants were selected for their potency in controlling plant diseases and pests in Nigeria (Adesegun, et al., 2012; Enikuomehin and Peters, 2002; Ogbebor and Adekunle, 2008).

Preparation of the Bioextracts: Distilled water was used as solvent for the extraction of plant materials. The crude extracts was obtained by first of all sterilizing plant parts in $1 \%$ Sodium hypochlorite $(\mathrm{NaOCl})$ for 1 minute, washed 3 times in distilled water, and later air dried. Thereafter, the plant materials were ground using a sterile manual grinder (Amadioha, 2004), and sieved in a 40 $\mathrm{mm}$ sieve into a fine powder. $100 \mathrm{~g}$ of the plant powder (packaged according to plant species and part) was soaked in one liter of distilled water, vigorously agitated, allowed to stand overnight then strained separately through double folds of sterile cheese cloth. This was used as the bioextracts in the experiment

Application of the Bio-Extracts in the Field: Hand sprayer was used to apply the bioextracts. Bioextracts of leaves, seed, bark and root of Azadirachta indica and Moringa oleifera, antibiotic and distilled water (control) was applied at 3, 5, 7 and 9 weeks after planting (WAP).

Field Assessment of Disease Incidence and Severity: The plants were examined for disease symptoms fortnightly from 6 weeks after planting (WAP) and number of plants/fruits infected was recorded until 12 WAP. Assessment of the number of infected plants was done per plot, the total number of plants and number infected in a plot were counted and the percentage disease incidence on leaves and fruit was calculated using the formula:

Percent Disease Incidence $(\mathrm{PDI})=\underline{\text { Number of plants infected in the sampled area }} \times \underline{100}$ Total number of plants assessed in the sampled area 1

Assessment of disease severity on leaves was by counting the number of lesions on the first five leaves of the randomly tagged plants and rating the symptom expression on a scale of 0-6 (a modified scale of Opara and Wokocha , 2008) where;

$0=$ Leaves without spot,

$1=$ one or two spots on leaves,

$2=10 \%$ of the leaves covered with spots,

$3=25 \%$ of the leaves covered with spots,

$4=1 / 2(50 \%)$ of the leaves covered with spots,

$5=4 / 5(75 \%)$ of the leaves affected,

$6=$ the entire leaf area affected or leaf dead.

Assessment of disease severity on fruits was by a scale of 1-6 where;

$1=$ No symptom on fruit surface,

$2=\mathrm{A}$ few water soaked dark lesions about $5 \%$ or less on the fruit surface,

$3=10-20 \%$ of the fruit surface covered with lesions/spots,

$4=25 \%$ portion but less than $50 \%$ of the fruit covered by lesions/spots,

$5=50 \%$ of the fruit covered with lesions and the lesions coalesce to form large dead spots

$6=70 \%$ and above of the fruit surface covered by lesions/and may crack and fruits completely collapse. 
Asuquo, Aniebiet Austin \& Opara Emma Umunna "Application of some Management Strategies on Leaf Spot and Fruit Rot Diseases of Watermelon (Citrullus Lanatus) in South Eastern Nigeria"

Disease severity was expressed as the mean of the severity scores recorded on plants, this was calculated using the formula; Disease severity $=$ Sum of individual ratings

Total number of plants examined

Assessment of Growth and Yield Parameters: The growth and yield parameters assessed were;

Total Number of Leaves: this was obtained by counting the total number of leaves on each of the randomly tagged plants

Number of Flowers: this was also by counting the number of the flowers

Vine Length (cm): this was done using a measuring tape

Number of Fruits: this was done by counting the number of fruits on the randomly tagged plants.

Fruit Weight at Harvest (kg): harvested fruits were weighed using a $5 \mathrm{~kg}$ weighing balance

\section{RESULTS}

Soil Analysis and Characterization of the Experimental Site

Tests conducted showed that the soil of the experimental site was sandy clay loam, acidic and low in nitrogen level (Table 1).

Table1. Physico-chemical Properties of Soil of the Experimental Site

\begin{tabular}{|l|l|}
\hline Physical properties & $\mathbf{( \% )}$ \\
\hline Sand & 69.20 \\
\hline Silt & 2.50 \\
\hline Clay & 28.30 \\
\hline Texture & Sandy clay loam \\
\hline Chemical properties & \\
\hline $\mathrm{pH}\left(\mathrm{H}_{2} 0\right)$ & 4.94 \\
\hline Available phosphorus $\left(\mathrm{mg} \mathrm{Kg}^{-1}\right)$ & 28.80 \\
\hline Total Nitrogen & 0.08 \\
\hline Organic matter & 2.05 \\
\hline Organic carbon & 1.20 \\
\hline Exchangeable bases & $\left(\mathbf{c m o l ~ \mathbf { ~ g } ^ { - 1 } )}\right.$ \\
\hline Calcium & 4.60 \\
\hline Magnesium & 2.20 \\
\hline Potassium & 0.13 \\
\hline Sodium & 0.11 \\
\hline Exchangeable acidity & 1.32 \\
\hline
\end{tabular}

Source: Soil Science Laboratory, National Root Crops Research Institute (2015)

Effect of Bioextracts on Disease Incidence and Severity, Growth and Yield Parameters of Watermelon

The results of the effects of different bioextracts against leaf spots and fruit rot diseases of watermelon are shown in Tables 2 - 6.

At six weeks after planting (WAP), results showed that there were significant differences $(\mathrm{P} \leq 0.05)$ in disease and growth parameters but not in yield attributes:

\section{Leaf Disease Incidence and Severity}

The untreated control (sterile water) was least effective $(54.90 \%)$ at probability of $5 \%$ and this was followed by $M$. oleifera bark $(49.76 \%)$. However, the best in reducing disease incidence was $A$. indica seed (15.75\%) although Streptomycin (a check) had $13.8 \%$ as a synthetic chemical. Also, $M$. oleifera bark and leaf were better than the control in reducing leaf disease severity with a record of 1.63 and 1.53 respectively with $A$. indica seed and A. indica leaf scoring the same value of 1.00 (Table 2).

\section{Growth Parameters}

On vine length, A. indica seed performed best $(73.67 \mathrm{~cm})$ even better than Streptomycin with $(72.33 \mathrm{~cm})$. The lowest vine length of $41.33 \mathrm{~cm}$ and $43.00 \mathrm{~cm}$ were recorded by the untreated control though not significantly different from $M$. oleifera bark (Table 2) 
Asuquo, Aniebiet Austin \& Opara Emma Umunna "Application of some Management Strategies on Leaf Spot and Fruit Rot Diseases of Watermelon (Citrullus Lanatus) in South Eastern Nigeria"

Streptomycin treated plots proved superior in terms of number of branches (4.00), followed by $A$. indica leaf with 2.37 while the untreated control, M. oleifera bark and M. oleifera leaf scored the minimum number of branches with 0.10

Highest number of leaves was recorded by A. indica seed (26.33), followed by streptomycin (23.33). The untreated control scored the least number of leaves (8.00) and was closely followed by $M$. oleifera bark (9.33)

Table2. Effect of bioextracts on leaf spots and fruit rot disease, growth and yield parameters of watermelon at 6 weeks after planting

\begin{tabular}{|l|l|l|l|l|l|l|}
\hline Treatment & Lf Inc. $(\%)$ & Lf Dis. & V/L $(\mathrm{cm})$ & No. $\mathrm{Br}$ & No. Lf & No Fl \\
\hline A. indica Seed & 15.75 & 1.00 & 73.67 & 2.03 & 26.33 & 1.70 \\
\hline A. indica Leaf & 24.45 & 1.00 & 65.67 & 2.37 & 21.33 & 0.40 \\
\hline A. indica Bark & 28.71 & 1.23 & 63.33 & 0.70 & 19.67 & 0.40 \\
\hline A. indica Root & 34.72 & 1.34 & 60.67 & 0.70 & 16.67 & 0.40 \\
\hline M. oleifera Seed & 36.11 & 1.19 & 58.67 & 1.07 & 16.33 & 0.40 \\
\hline M. oleifera Leaf & 44.11 & 1.53 & 49.00 & 0.10 & 11.00 & 0.10 \\
\hline M. oleifera Bark & 49.76 & 1.63 & 43.00 & 0.10 & 9.33 & 0.10 \\
\hline M. oleifera Root & 41.69 & 1.38 & 53.67 & 0.40 & 14.00 & 0.10 \\
\hline Streptomycin & 13.81 & 0.70 & 72.33 & 4.00 & 23.33 & 1.37 \\
\hline Control & 54.90 & 1.69 & 41.33 & 0.10 & 8.00 & 0.10 \\
\hline LSD $(\mathrm{P} \leq 0.05)$ & $9.10^{* *}$ & $0.34 * *$ & $5.89^{* *}$ & $2.25^{*}$ & $3.42^{* *}$ & NS \\
\hline
\end{tabular}

Legend: $\quad$ NS $=$ Not significant $(\mathbf{P} \leq \mathbf{0 . 0 5})$

$$
\begin{aligned}
& *=\text { Significant } \\
& * *=\text { Highly significant }
\end{aligned}
$$

Lf Inc = Leaf disease Incidence, $\mathrm{Lf}$ Dis = Leaf Disease severity, $\mathrm{V} / \mathrm{L}=$ Vine length, $\mathrm{No} \mathrm{Br}=$ Number of Branches, No FI $=$ Number of Flowers, No Frt $=$ Number of Fruits, Frt Inc $=$ Fruit disease Incidence, Frt Dis $=$ Fruit Disease severity

Effect of Bioextracts on Disease Incidence and Severity, Growth and Yield Parameters of Watermelon (8 Weeks after Planting)

At 8 weeks after planting (WAP), the results of the effect of different bioextracts on leaf and fruit rot disease of watermelon showed significant $(\mathrm{P} \leq 0.05)$ differences among all the parameters assessed except number of branches (Table 3).

\section{Leaf and Fruit Disease Incidence and Severity}

In terms of leaf disease incidence, Streptomycin recorded the best (31.88\%) in controlling incidence followed by $A$. indica seed $(43.75 \%)$ and these differed statistically $(\mathrm{P} \leq 0.05)$ from the untreated control which had the highest disease incidence of $83.07 \%$. On leaf disease severity, the control produced leaves with the highest disease severity (3.66), while lowest disease severity was recorded by $A$. indica seed (2.13) after streptomycin (1.75).

Highest Fruit disease incidence and severity was recorded by the untreated control $(50.03 \%)$ and (1.70) respectively followed by $M$. oleifera bark with $16.73 \%$ fruit disease incidence and 0.73 fruit disease severity. The antibiotic, $A$. indica seed, leaf, bark, root, M.oleifera seed, leaf and root recorded the least disease incidence and severity $(0.10)$

\section{Growth and Yield Parameters}

A. indica seed gave the highest vine length of $112.00 \mathrm{~cm}$ and was found better than Streptomycin with $106.67 \mathrm{~cm}$, the least vine length was recorded by the untreated control $57.33 \mathrm{~cm}$ followed by $M$. oleifera bark $(63.33 \mathrm{~cm})$.

At eight weeks after planting (WAP), it was observed that $A$. indica seed produced the highest number of leaves (39.00), and number of flowers (20.67) better than Streptomycin (34.00) while the untreated control produced the lowest number of leaves (11.33). 
Asuquo, Aniebiet Austin \& Opara Emma Umunna "Application of some Management Strategies on Leaf Spot and Fruit Rot Diseases of Watermelon (Citrullus Lanatus) in South Eastern Nigeria"

Significant differences were observed on number of fruits with $A$. indica seed, and streptomycin producing the highest number of fruits (5.00), while the untreated control, M. oleifera bark and $M$. oleifera leaf gave the least number of fruits (1.67).

Table3. Effect of bioextracts on leaf spots and fruit rot disease, growth and yield parameters of watermelon at 8 weeks after planting

\begin{tabular}{|l|l|l|l|l|l|l|l|l|l|}
\hline Treatment & $\begin{array}{l}\text { Lf Inc } \\
(\%)\end{array}$ & Lf Dis & $\begin{array}{l}\text { V/L } \\
(\mathrm{cm})\end{array}$ & No Br & No Lf & No Fl & No Frt & $\begin{array}{l}\text { Frt Inc } \\
(\%)\end{array}$ & Frt Dis \\
\hline A. indica Seed & 43.75 & 2.13 & 112.00 & 5.00 & 39.00 & 20.67 & 5.00 & 0.10 & 0.10 \\
\hline A. indica Leaf & 47.23 & 2.33 & 101.67 & 3.67 & 31.67 & 11.33 & 3.67 & 0.10 & 0.10 \\
\hline A. indica Bark & 59.40 & 2.47 & 91.67 & 3.37 & 29.33 & 3.67 & 2.33 & 0.10 & 0.10 \\
\hline A. indica Root & 61.89 & 2.77 & 88.67 & 3.70 & 27.67 & 6.00 & 2.33 & 0.10 & 0.10 \\
\hline M. oleifera Seed & 62.31 & 2.81 & 83.33 & 3.00 & 25.33 & 5.00 & 3.00 & 0.10 & 0.10 \\
\hline M. oleifera Leaf & 73.74 & 3.13 & 66.67 & 1.67 & 18.33 & 3.33 & 1.67 & 0.10 & 0.10 \\
\hline M. oleifera Bark & 77.06 & 3.61 & 63.33 & 1.67 & 14.33 & 1.00 & 1.67 & 16.73 & 0.73 \\
\hline M. oleifera Root & 69.03 & 3.07 & 73.67 & 2.70 & 21.00 & 3.67 & 2.00 & 0.10 & 0.10 \\
\hline Streptomycin & 31.88 & 1.75 & 106.67 & 5.00 & 34.33 & 14.67 & 5.00 & 0.10 & 0.10 \\
\hline Control & 83.07 & 3.66 & 57.33 & 1.33 & 11.33 & 1.33 & 1.33 & 50.03 & 1.700 \\
\hline LSD P $\leq 0.05)$ & $14.35^{* *}$ & $0.79^{* *}$ & $15.20^{* *}$ & NS & $3.31^{* *}$ & $6.13 * *$ & $1.52^{* *}$ & $31.06^{*}$ & $0.99^{*}$ \\
\hline
\end{tabular}

Legend: $\quad N S=$ Not significant $(P \leq 0.05)$

$$
\begin{aligned}
* & =\text { Significant } \\
* * & =\text { Highly significant }
\end{aligned}
$$

Lf Inc = Leaf disease Incidence, $\mathrm{Lf}$ Dis = Leaf Disease severity, $\mathrm{V} / \mathrm{L}=$ Vine length, $\mathrm{No} B r=$ Number of Branches, No FI $=$ Number of Flowers, No Frt $=$ Number of Fruits, Frt Inc $=$ Fruit disease Incidence, Frt Dis = Fruit Disease severity

Effect of Bioextracts on Disease Incidence and Severity, Growth and Yield Parameters of Watermelon (10 Weeks after Planting)

The effects of different bioextracts used on the control of leaf spots and fruit rot diseases, growth and yield parameters of watermelon at $10 \mathrm{WAP}$ is shown in Table 4

\section{Leaf Disease Incidence and Severity, and Fruit Disease Incidence}

In terms of Leaf disease incidence, severity and fruit disease incidence, $A$. indica seed had the lowest leaf incidence of $(56.84 \%)$, leaf disease severity of (2.39) and fruit disease incidence of (6.37\%) next to the standard chemical with least leaf incidence (49.38\%), least leaf disease severity (1.72), and least fruit disease incidence $(5.44 \%)$ which was statistically $(\mathrm{P} \leq 0.05)$ different from the untreated control which recorded highest leaf disease incidence (82.82), highest leaf disease severity (4.10) and highest fruit disease incidence (64.44\%)

\section{Growth and Yield Parameters}

The results showed that apart from number of branches and fruit disease severity, all other parameters were significantly $(\mathrm{P} \leq 0.05)$ different with $A$. indica seed producing the best results in all the growth and yield parameters in terms of vine length $(131 \mathrm{~cm})$, number of leaves $(44.00)$, number of flowers (16.33) and number of fruits (13.33) better than the control including the standard check (Streptomycin) with vine length of $(131 \mathrm{~cm})$, number of leaves (40.33), number of flowers (9.33), and number of fruits $(11.00)$ and all these were significantly $(\mathrm{P} \leq 0.05)$ different when compared with the untreated control with the least vine length $(67.33 \mathrm{~cm})$, number of branches $(2.33$, number of leaves (21.33) and number of fruits (5.33). Table 4

Table4. Effect of bioextracts on leaf spots and fruit rot disease, growth and yield parameters of watermelon at 10 weeks after planting

\begin{tabular}{|l|l|l|l|l|l|l|l|l|l|}
\hline Treatment & $\begin{array}{l}\text { Lf Inc } \\
(\%)\end{array}$ & Lf Dis & $\begin{array}{l}\text { V/L } \\
(\mathrm{cm})\end{array}$ & $\begin{array}{l}\text { No } \\
\mathrm{Br}\end{array}$ & No Lf & No Fl & No Frt & $\begin{array}{l}\text { Frt Inc } \\
(\%)\end{array}$ & $\begin{array}{l}\text { Frt } \\
\text { Dis }\end{array}$ \\
\hline A. indica Seed & 56.84 & 2.39 & 131.67 & 7.00 & 44.00 & 16.33 & 13.33 & 6.37 & 1.07 \\
\hline A. indica Leaf & 61.90 & 2.61 & 120.00 & 6.00 & 36.00 & 5.00 & 10.00 & 6.73 & 1.07 \\
\hline A. indica Bark & 66.90 & 3.02 & 105.00 & 4.33 & 30.33 & 3.67 & 8.67 & 8.37 & 2.03 \\
\hline A. indica Root & 71.70 & 3.17 & 100.00 & 4.00 & 28.00 & 5.00 & 7.67 & 9.55 & 1.70 \\
\hline
\end{tabular}


Asuquo, Aniebiet Austin \& Opara Emma Umunna "Application of some Management Strategies on Leaf Spot and Fruit Rot Diseases of Watermelon (Citrullus Lanatus) in South Eastern Nigeria"

\begin{tabular}{|l|l|l|l|l|l|l|l|l|l|}
\hline M. oleifera Seed & 76.97 & 3.00 & 94.33 & 5.00 & 26.67 & 4.67 & 7.00 & 13.92 & 1.70 \\
\hline M. oleifera Leaf & 79.09 & 3.47 & 85.00 & 4.00 & 20.67 & 2.33 & 4.67 & 27.77 & 3.00 \\
\hline M. oleifera Bark & 81.25 & 3.73 & 73.00 & 2.00 & 18.00 & 3.00 & 4.00 & 41.11 & 3.00 \\
\hline M. oleifera Root & 77.09 & 3.50 & 88.33 & 4.00 & 23.67 & 4.67 & 5.67 & 16.22 & 1.70 \\
\hline Streptomycin & 49.38 & 1.72 & 131.67 & 6.00 & 40.33 & 9.33 & 11.00 & 5.44 & 0.73 \\
\hline Control & 88.82 & 4.10 & 67.33 & 2.00 & 15.33 & 3.00 & 3.67 & 64.44 & 3.33 \\
\hline LSD $(\mathrm{P} \leq 0.05)$ & $15.22^{* *}$ & $0.68^{* *}$ & $9.13^{* *}$ & NS & $2.47^{* *}$ & $6.40^{* *}$ & $1.94^{* *}$ & $14.11^{* *}$ & NS \\
\hline
\end{tabular}

Legend: $\quad$ NS $=$ Not significant $(\mathbf{P} \leq \mathbf{0 . 0 5})$

$$
\begin{aligned}
& *=\text { Significant } \\
& * *=\text { Highly significant }
\end{aligned}
$$

Lf Inc = Leaf disease Incidence, $\mathrm{Lf}$ Dis = Leaf Disease severity, $\mathrm{V} / \mathrm{L}=$ Vine length, $\mathrm{No} \mathrm{Br}=$ Number of Branches, No FI $=$ Number of Flowers, No Frt $=$ Number of Fruits, Frt Inc $=$ Fruit disease Incidence, Frt Dis = Fruit Disease severity

Effect of Bio-Extracts on Disease Incidence and Severity, Growth and Yield Parameters of Watermelon (12 Weeks after Planting)

At 12 Weeks after planting, all the parameters tested showed significant $(\mathrm{P} \leq 0.05)$ difference except number of flowers.

\section{Leaf and Fruit Disease Incidence and Severity}

Highest leaf disease incidence was recorded by the untreated control $(91.33 \%)$ followed by $M$. oleifera bark $(89.10 \%)$ and M. oleifera leaf $(85.10 \%)$. Streptomycin had the least disease incidence (54.22\%) followed by $A$. indica seed (61.23\%) and A. indica leaf (67.16\%). Highest leaf disease severity was also recorded by the untreated control (5.12) followed by M. oleifera bark (4.70) and M. oleifera leaf (4.11). The least leaf disease severity was obtained from the standard (Streptomycin) with (10.67) followed by A. indica seed (2.64) and A. indica leaf (2.82).

It was observed that even at $12 \mathrm{WAP}$, the antibiotic consistently produced crops with the least fruit disease incidence (30.16\%), and severity (2.33) followed by A. indica seed with (35.51\%) and (3.33) respectively and it was statistically different from the untreated control which gave fruits with the highest disease incidence (87.78\%) and severity (5.67)

Growth and Yield Parameters

A. indica seed consistently produced the highest vine length $(140 \mathrm{~cm})$, number of branches $(8.00)$, number of leaves (49.00) and number of fruits followed by Streptomycin and these were statistically $(\mathrm{P} \leq 0.05)$ different from the control which produced crops with the lowest growth and yield parameters (Table 5).

Table5. Effect of bio-extracts on leaf spots and fruit rot disease, growth and yield parameters of watermelon at 12 weeks after planting

\begin{tabular}{|l|l|l|l|l|l|l|l|l|l|}
\hline Treatment & $\begin{array}{l}\text { Lf Inc } \\
(\%)\end{array}$ & Lf Dis & $\begin{array}{l}\text { V/L } \\
(\mathrm{cm})\end{array}$ & No Br & No Lf & No Fl & No Frt & $\begin{array}{l}\text { Frt Inc } \\
(\%)\end{array}$ & Frt Dis \\
\hline A. indica Seed & 61.27 & 2.64 & 140.00 & 8.00 & 49.00 & 1.37 & 16.00 & 35.51 & 3.33 \\
\hline A. indica Leaf & 67.06 & 2.82 & 129.00 & 6.33 & 40.00 & 0.73 & 12.00 & 39.08 & 3.67 \\
\hline A. indica Bark & 73.10 & 3.27 & 113.33 & 4.67 & 37.67 & 0.10 & 11.33 & 44.19 & 4.00 \\
\hline A. indica Root & 78.91 & 3.49 & 107.33 & 4.33 & 34.67 & 0.10 & 10.00 & 52.99 & 4.00 \\
\hline M. oleifera Seed & 80.95 & 3.44 & 102.00 & 5.33 & 33.33 & 0.10 & 10.00 & 56.67 & 4.00 \\
\hline M. oleifera Leaf & 85.51 & 4.11 & 91.33 & 4.67 & 28.00 & 0.10 & 7.67 & 69.64 & 5.00 \\
\hline M. oleifera Bark & 89.10 & 4.70 & 78.33 & 2.67 & 24.33 & 0.10 & 6.67 & 75.39 & 5.33 \\
\hline I. oleifera Root & 82.46 & 3.67 & 92.67 & 4.33 & 30.67 & 0.73 & 9.33 & 64.44 & 4.33 \\
\hline Streptomycin & 54.22 & 1.94 & 137.33 & 7.00 & 44.33 & 1.03 & 13.33 & 30.16 & 2.33 \\
\hline Control & 91.33 & 5.12 & 73.67 & 2.33 & 21.33 & 0.10 & 5.33 & 87.77 & 5.67 \\
\hline LSD $(\mathrm{P} \leq 0.05)$ & $11.42^{* *}$ & $0.46^{* *}$ & $9.00^{* *}$ & $3.17 *$ & $2.49 * *$ & NS & $1.32^{* *}$ & $11.62^{* *}$ & $1.43^{* *}$ \\
\hline
\end{tabular}

Legend: $\quad N S=$ Not significant $(P \leq 0.05)$

$$
\begin{aligned}
& *=\text { Significant } \\
& * *=\text { Highly significant }
\end{aligned}
$$

International Journal of Research in Agriculture and Forestry V4 • I2・ February 2017 
Asuquo, Aniebiet Austin \& Opara Emma Umunna "Application of some Management Strategies on Leaf Spot and Fruit Rot Diseases of Watermelon (Citrullus Lanatus) in South Eastern Nigeria"

Lf Inc = Leaf disease Incidence, $\mathrm{Lf}$ Dis = Leaf Disease severity, $\mathrm{V} / \mathrm{L}=$ Vine length, $\mathrm{No} \mathrm{Br}=$ Number of Branches, No Fl $=$ Number of Flowers, No Frt $=$ Number of Fruits, Frt Inc $=$ Fruit disease Incidence, Frt Dis = Fruit Disease severity

\section{Effect of Bio-extracts on Yield of Watermelon}

The result of the different bioextracts on yield of watermelon was significant $(\mathrm{P} \leq 0.05)$. It was observed that the antibiotic displayed superiority over all the other treatments to produce fruits with the highest weight $(6.09 \mathrm{~kg})$ followed by A. indica seed $(4.96 \mathrm{~kg})$ and A. indica leaf $(3.99 \mathrm{~kg})$. The least fruit weight was recorded by the untreated control $(0.33 \mathrm{~kg})$ followed by M. oleifera bark $(0.48 \mathrm{~kg})$

Table6. Effect of bio-extracts on yield of watermelon at harvest

\begin{tabular}{|l|l|}
\hline Treatment & Fruit weight $(\mathrm{Kg}) /$ plant \\
\hline & \\
\hline A. indica Seed & .96 \\
\hline A. indica Leaf & 3.99 \\
\hline A. indica Bark & 3.03 \\
\hline A. indica Root & 2.40 \\
\hline M. oleifera Seed & 1.62 \\
\hline M. oleifera Leaf & 0.81 \\
\hline M. oleifera Bark & 0.48 \\
\hline M.oleifera Root & 1.33 \\
\hline Streptomycin & 6.09 \\
\hline Control & 0.33 \\
\hline LSD $(\mathrm{P} \leq 0.05)$ & 0.62 \\
\hline
\end{tabular}

\section{DISCUSSION}

The use of bioextracts in disease control has generated interest in developing countries due to high cost of synthetic pesticides and their hazardous effects on the environment (Schmutterer, 1990; Tovingan et al., 2001 and Salako, 2002). Results from this study showed that disease incidence and severity of leaf spot and fruit rot of watermelon was significantly reduced by the application of different plant parts used as bioextracts. Almost all the bioextracts used (except M. oleifera bark and M. oleifera leaf) significantly $(\mathrm{P} \leq 0.05)$ reduced severity and infection on leaves and fruit. However, Percentage of leaves and fruits infected as well as severity was particularly lower for bioextracts of $A$. indica especially $A$. indica seed and $A$. indica leaf. While the antibiotic, streptomycin substantially reduced incidence and severity of the diseases, it was statistically $(\mathrm{P} \leq 0.05)$ at par with bioextracts of $A$. indica seed and A. indica leaf. This confirms the earlier reports that many plant products contain anti-bacterial and fungitoxic constituents that have the potentials to control plant diseases (Emechebe and Alabi 1997; Amadioha, 2000; Enikuomehin and Peters, 2002; Balm, 2003; Bdliya and Dahiru, 2006; Opara and Wokocha, 2008; Okigbo, 2009; Opara and Agugo, 2014a). It was observed that the A. indica treated plants also performed better than plants treated with $M$. oleifera in terms of growth and yield parameters assessed throughout the study. Bioextracts of $M$. oleifera bark and leaf recorded the least performance after control in terms of growth and yield attributes and also had the highest disease incidence and severity after the untreated control.

The consistent best performance of bioextracts of A. indica was in line with those of Bdliya and Dahiru (2006) who showed that aqueous extract of neem leaf and seed aqueous extract significantly reduced the incidence and severity of tuber soft rot. Opara and Wokocha, 2008 reported that aqueous extracts of A. indica seed was most effective and comparable to Streptomycin in inhibiting the bacterial leaf spot pathogen (Xanthomonas campestris pv vesicatoria) on tomato in vitro and in vivo. Emechebe (1996) found foliar applications of aqueous neem seed extracts to be effective in controlling bacterial blight of cowpea. Asma et al. (2014) reported that beside turmeric, neem significantly $((\mathrm{P} \leq 0.05)$ reduced bacterial soft rot of tomato and resulted in maximum height, fresh shoot weight, dry shoot weight and dry root weight. Similar observations were made by Opara and Agugo, 2014a. These authors reported that A. indica aqueous extract achieved the best reduction of bacterial disease severity and disease incidence on mungbean and had the highest number of pods $(23.20 \mathrm{~g})$, and seed weight $(41.68 \mathrm{~g})$ per plant which was significantly better than control $(8.6 \mathrm{~g}$ and $2206 \mathrm{~g}$ respectively). In a related study, Opara and Agugo, 2014b also observed that A. indica seed oil was most effective against Ralstonia (Pseudomonas) and Flavobacteria (Xanthomonas) and 
Asuquo, Aniebiet Austin \& Opara Emma Umunna "Application of some Management Strategies on Leaf Spot and Fruit Rot Diseases of Watermelon (Citrullus Lanatus) in South Eastern Nigeria"

compared favourably with the antibiotics (Streptomycin) in inhibiting soft rot of sweet potato (Ipomoea batatas Lam.) in vitro. Mumuni et al., 2013 reported that neem kernel water extract and neem kernel powder were efficacious and comparable to chlorpyrifos in lowering populations of soil arthropods and severity of leaf spot diseases resulting in increased pod yield in peanut.

According to Edeoga et al., 2005; Shukla et al. (2012) some medicinal plants contain a wide range of bioactive secondary metabolites including: alkaloids, flavonoids, tannins, saponins, phenols, phlobatannins quinones, lecitins, polyphenols, glycosides, terpenoids, polypeptides and steroids. In a review of some bioextracts plants proximate contents Enyiukwu and Awurum, (2013) reported similar observation. These bioactive compounds of natural products have been given as the reason for their inhibitive roles against pathogens in plant health management (Okwu and Njoku, 2009; Enyiukwu et al., 2013). Williams (2005) and also Opara and Wokocha (2008) reported that the bactericidal properties of $A$. indica could be attributed to its phytochemical components. Neem has a blend of 3 related compounds along with over 20 lesser ones, which are equally active (Asma et al. 2014). The general class of these compounds is triterpenes and within this category, the most effective are the limonoids, which are abundant in A. indica, of these limonoids, azadirachitin has been found to be the main anti-microbial, being up to $90 \%$ effective in most instances. Koul et al. (1989) reported that azadirachitin repels and disrupts pathogen life cycles, and is one of the most effective growth and feeding deterrents ever examined. They also observed that nimbin and nimbidin, also found in $A$. indica have anti-viral properties and these have been shown to be effective in inhibiting fungal growth as well. Williams (2005) observed that bioextracts of plant are systemic in action like some known bactericides and has significant effect on the pathogen leading to the bactericidal activities which in turn result in increased growth parameters and crop yield. Similar observations were made by several other researchers (Thoeming and Poehling, 2006; Thoeming et al., 2006; Mumuni et al., 2013 and Tijani et al., 2014).

However, although the antibiotic (Streptomycin) enhanced fruit yield, it was statistically $(p<0.05)$ at par with almost all the bioextracts especially A. indica seed and leaf. This could be attributed to disruption of photosynthesis occasioned by high leaf disease incidence and severity recorded with other treatments when compared with A. indica seed and leaf. Hoda et al. (2005) observed that development of chlorosis in tomato leaves is attributed to interference of the pathogen (Xanthomonas campestris pv. vesicatoria) with photosynthesis. Amadi et al. (2009) observed that leaf spot might have reduced the photosynthetic surface of the leaves available for food manufacture and consequently results in reduction of fruit sizes in infected watermelon. Plant nutrients are produced in the leaf cells during photosynthesis, and are translocated downward and distributed to all the living plant cells (Agrios, 2005). In advanced stages of some diseases, the rate of photosynthesis is not more than one-fourth the normal rate (Agrios, 2005), reduction of photosynthesis will result in reduction in growth and consequently in fresh and dry weight of the plant.

\section{CONCLUSION}

This study was carried out to ascertain the efficacy of plant derived pesticides in managing leaf spot and fruit rot of watermelon in Umudike, South Eastern Nigeria. The study showed that bioextracts from the different parts of A.indica and M.oleifera especially A. indica seed and A. indica leaf have potentials in the reduction of leaf spot and fruit rot of watermelon, therefore, due to the fact that chemical control of disease is environmentally hazardous and very expensive, these inexpensive, nonhazardous and bio-degradeable plant materials could be used as an alternative way of reducing and controlling these diseases by poor resource farmers. The added advantages to these are that plant derived pesticides leave no toxic load on produce, this therefore makes them a choice input particularly in organic farming and in low input conventional farming systems, they also require no pre-harvest interval (PHI) before treated produce can be harvested and consumed.

\section{REFERENCES}

[1] Adekunle, A. A., Fatunbi, A. O., Adisa, S., \& Adeyemi, O. A. (2007). Growing watermelon commercially in Nigeria: An illustrated guide. USAID ICS-NIGERIA and IITA. Retrieved October 5, 2015

[2] Adesegun, E.A., Ajayi, E.O., Adebayo, O.S., Akintokun, A.K., and Enikuomehin, O.A., (2012). Effect of Ocimum gratissimum (L.) and Aframomum melegueta (K. Schum.) Extracts on the Growth of Sclerotium rofsii (Sacc.). International Journal of Plant Pathology. ISSN 1996-0719/ DOI: $10.3923 / J P P$. 
Asuquo, Aniebiet Austin \& Opara Emma Umunna "Application of some Management Strategies on Leaf Spot and Fruit Rot Diseases of Watermelon (Citrullus Lanatus) in South Eastern Nigeria"

[3] Agrios, G.N. (2005). Plant Pathology, 5th Edition. Elsevier Academic Press. Burlington, MD.

[4] Amadi, J. E.; Adebola, M. O; and. Eze, C. S (2009). Isolation and identification of a bacterial blotch organism from watermelon (Citrullus lanatus (Thunb.) Matsum. and Nakai). African Journal of Agricultural Research 4(11): 1291-1294 Available online at http://www.academicjournals.org

[5] Amadioha, A. C. (2000) Controlling rice blast in vitro and in vivo with extracts of Azadirachta indica. Crop Protection 19: 287-290

[6] Amadioha, A. C. (2004). Control of black rot of potato caused by Rhyzoctonia bataticola using some leaf extracts.Arch. Phytopathol. Plant Prot. 37:111-117.

[7] Asma Akbar, Subhan ud Din, Mushraf Ahmad, Gul daraz Khan, Sartaj Alam (2014). Effect of Phytobiocides in Controlling Soft Rot of Tomato. Journal of Natural Sciences Research Vol.4, No.11.

[8] Babadoost Mohamad (2002). Report on Plant Disease (RPD No. 948). Department of Crop Sciences, University of Illinois at Urbana- Champaign.

[9] Bdliya BS, Dahiru B. (2006). Efficacy of some plant extracts in the control of potato tuber soft rot caused by Erwinia carotovora ssp caotovora. J Plant Prot Res, 46 (3):285-294.

[10] Bremmer JM and Mulvaney CS (1982). Total nitrogen In: Page A. L. Miller, R. H. and Keeney, D. R. (ed.) Methods of soil analysis. Part 2. Agron 9, Madison. W.I. p. 149-157.

[11] Edeoga, H. O., Okwu, D. E., Mbaebie BO, (2005). Phytochemical constituents of some Nigerian medicinal plants. Afr J Biotechnol, 4(7): 685-688.

[12] Emeasor, K. C., Ogbuji, R. O. and Emosairue, S. O. (2005). Insecticidal activity of some seed powders against Callosobruchus maculatus (F.) (Coleoptera: Bruchidae) on stored cowpea. Journal of Plant Diseases and Protection, 112 (1): 80-87.

[13] Emechebe, A.M. (1996). Evaluation of aqueous extracts of parts of some plants and black local soap solution for the control of cowpea diseases at Samaru. Cropping Scheme Meeting: Report on Legumes and Oil Seeds Research Programme 26th February-1st March, 1996. Pp. 79.

[14] Emechebe A.M., Alabi O. (1997). Evaluation of aqueous extracts of parts of some plants for the control of cowpea diseases at Samaru. Samaru Cropping Scheme Meeting, Samaru, Zaria, Nigeria: Report on Legumes and Oil seeds Research Programme, 77 pp.

[15] Emosairue, S.O., Ukeh, D.A., (1996). Field trail of neem products for the control of okra flea beetles (Podagrica spp) in South Eastern Nigeria. African J. Plant Protection 6, 27-33.

[16] Enikuomehin, O.A. and Peters, O.T. (2002). Evaluation of crude extracts from some Nigerian plants for the control of field diseases of sesame (Sesamum indicum L.). Trop. Oilseeds J., 7: 8493.

[17] Enyiukwu DN and Awurum AN, (2013). Fungitoxic principles and antifungal activity of extracts from Carica papaya and Piper guineense on Colletotrichum destructivum. Cont J Biol Sci, 7(1):29-36.

[18] Enyiukwu DN, Awurum AN, Ononju CC, Nwaneri JA, (2013). Significance of characterization of secondary metabolites from extracts of higher plants in plant disease management. Int $J A d v$ Agric Res. 2: 8-28

[19] Gee GW and Bauder JW (1986). Particle size analysis p. 404-407. In A Klute (ed) Methods of soil analysis. Part 1 (2nd ed.) Agron. Monogr.9. ASA and SSSA. Madison W.I. USA.

[20] George, A. (2004). Horticulture, principles and practice, second edition. http://www.fao.org/sd/erp/ toolkit/BOOKS/watermelon_illust_guidebook.pdf.

[21] Hoda H. El-Hendawy', Mohamed E. Osman, Noha M. Sorour (2005). Biological control of bacterial spot of tomato caused by Xanthomonas campestris pv. vesicatoria by Rahnella aquatilis. Microbiology Research Vol 160, Issue 4, pages 343-352.

[22] IITA International institute for Tropical Agriculture (1979). Laboratory manual for soil and plant analysis. Manual series 7, IITA, Ibadan, Nigeria

[23] IITA, (2013). Growing watermelon commercially in Nigeria- an illustrated guide.International Institute of Tropical Agriculture (IITA), pp1-16. 
Asuquo, Aniebiet Austin \& Opara Emma Umunna "Application of some Management Strategies on Leaf Spot and Fruit Rot Diseases of Watermelon (Citrullus Lanatus) in South Eastern Nigeria"

[24] Ikeorgu JEG (1991). Effects of maize and cassava on the performance of intercropped egusi melon (Citrullus lanatus (L.) Thunb.) and okra (Abelmoschus esculentus (L.) Moench.) in Nigeria. Sci. Hortic. Amsterdam, 48: 261-268.

[25] Jarret B, Bill R, Tom W and Garry A. (1996). Cucurbits Germplasm Report, pp: 29-66. Watermelon National Germplasm System, Agricultural Service, U.S.D.A.

[26] Koul O., M. Isman and Ketkar. (1989). Properties and uses of Neem, Azadirachta indica. Journal of Botany 68: 1-11.

[27] Lawal, A.B. (2000). Response of cucumber to intercropping with maize and varying rates of farmyard manure and inorganic fertilizer, Agriculture and Environment.2 (1): 78-83.

[28] Mangila E, Tabiliran FP, Naguit MRA and Malate R (2007). Effects of Organic Fertilizer on the Yield of Watermelon. Threshold 2. pp. 27-35.

[29] Martyn R. D., Miller ME, Bruton BD.ed. (1993). Common names of plant diseases: Diseases of cucurbits (Citrullus spp., Cucumis spp., Cucurbita spp., and others). A. M. Phytopathol. Soc.

[30] Mason, J. R., and Mathew D. N. (1996) Evaluation of neem as a bird repellent chemical. International Journal of Pest Management 42:47-49

[31] Matanyaire CM (1998). Sustainability of pearl millet (Pennisetum glaucum) productivity in northern Namibia: current situation and challenges. S. Afr. J. Sci., 94: 157-816

[32] Mumuni Abudulai, Abdulai B. Salifu, Danial Opare-Atakora, Mohammed Haruna, Inusah I.Y. Baba, Israel K. Dzomeku, Rick L. Brandenburg and David L. Jordan (2013). Field Efficacy of Neem (Azadirachta indica A. Juss) for Managing soil arthropods and cercospora leaf spots damage for increased yield in peanut. Plant Protect. Sci. Vol. 49, No. 2: 65-72

[33] Ndoro, O. F., Madakadze, R. M., Kageler, S., Mashingaidze, A. B. (2007). Indigenous knowledge of the traditional vegetable pumpkin (Cucurbita maxima/moschata) from Zimbabwe. Afr. J. Agr. Res., 2: 649-655.

[34] Nelson DW and Sommers IE (1982). Organic Carbon. In Page A.L. Miller, R. H. and Keeney, D. R. (ed) Methods of Soil analysis. Part 2 Agron, Monogr. 9 ASA and SSSA, Madison, W.I. USA.

[35] NRCRI (2010). National Root Crops Research Institute. NRCRI, Umudike Meteorological Station Data, 2010

[36] Ogbebor, O.N., Adekunle, A.T., and Ellis, M. B. (2008). Inhibition of Drechslera heveae (Petch) causal organism of Bird's eye spot disease of rubber (Hevea brasiliensis Muell Arg.) using plant extracts. African Journal of General Agriculture. Vol. No. 1,

[37] Okigbo RN. (2009). Variation in phytochemical properties of selected fungicidal aqueous extract of some plant leaves in Kogi State, Nigeria. American Eurossian Journal of Sustainable Agriculture 3(3), 407-409.

[38] Okwu, D.E., Njoku. E.E. (2009). Chemical composition and In vitro antifungal activity screening of seed and leaf extracts from Afromonum melenguata and Monodora myristica against Sclerotium rolfsii of cowpea plant. Pest Tech, 3(1):58-67.

[39] Opara, E.U. and Agugo, B.A. (2014). Application of Organic Amendments and Botanical Foliar Sprays against Bacterial Diseases of Mungbean (Vigna radiata L.) in South Eastern Nigeria. Greener Journal of Agricultural Sciences Vol. 4 (2), pp. 052-057

[40] Opara, E.U. and Agugo, B.A. (2014). Control of Posthavest Rot of Sweeetpotato (Ipomoea batatas Lam.) Tuber in Vitro and in Vivo. Journal of Agriculture and Sustainability 6 (1): 50-68

[41] Opara, E.U, Wokocha RC, (2008). Efficacy of some plant extracts on the in vitro and in vivo control of Xanthomonas campestris pv vesicatoria. Medwell Agric Journal 3(3):163-170.

[42] Qasem, J.R., Abu-Blan, H.A., (1966). Fungicidal activity of some common weed extracts against different plant pathogenic fungi. J. Phytopathol. 144, 157-161.

[43] Roades, J. D. (1982). Cation Exchange Capacity. In Page, A. L. Miller, R. H. and Keeney, D.R. (eds) Methods of soil analysis. Part 2 Agron. Monogr. ASA, SSSA, Madison, W.I. USA.

[44] Roberts P, Kucharek T. (2006). Florida plant Disease Management Guide: Watermelon. http:// Watermelon. Ifas.ufl.edu/disease.htm

[45] Robinson, R.W. and Decker-Walters Ragavan, D.S. (1997). Cucurbits. New York Cab International, pp: 226. (Crop Production Science in, Horticulture nE.6) 
Asuquo, Aniebiet Austin \& Opara Emma Umunna "Application of some Management Strategies on Leaf Spot and Fruit Rot Diseases of Watermelon (Citrullus Lanatus) in South Eastern Nigeria"

[46] Salako, E. A. (2002). Plant protection for the Resource poor farmers. Paper presented at the $30^{\text {th }}$ annual conference of Nigeria Society of Plant Protection, UNAAB Abeokuta. Pp.1-4.

[47] Schmutterer H. (1990): Properties and potential of natural pesticides from the neem tree, Azadirachta indica. Annual Review of Entomology, 35: 271-297.

[48] Shukla AM, Yadav RS, Shashi SK, Dikshit A, (2012). Use of plant metabolites as an effective source for the management of post-harvest fungal pest: A review. Int J Curr Discoveries Innovations, 1(1): 33-45.

[49] Singh, D.C., (1994). Scope of medicinal and aromatic plants in pest management. International Symposium, Allelopathy in sustainable Agriculture, Forestry and Environment, New Delhi, September 6-81994. p. 68.

[50] Steel, R. G. and Torrie, J. H. (1997). Principles and procedures of statistics. New York: McGraw, 1960.

[51] Tewari, S.N. and Nayak, M., (1991). Activity of four-plant leaf extracts against three fungal pathogens of rice. Tropical Agric. (Trinidad) 68, 373-375.

[52] Thoeming G. Poehling H. M. (2006): Integrating soil applied Azadirachtin with Amblyseius cucumeris (Acari:Phytoseiidae) and Hypoaspis aculeifer (Acari: Laelapidae) for the management of Frankliniella occidentalis (Thysanoptera:Thripidae). Environmental Entomology, 35:746756.

[53] Thoeming G., Draeger G., Poehling H.-M (2006): Soil application of azadirachtin and 3-tigloylazadirachtol to control western flower thrips, Frankliniella occidentalis (Thysanoptera: Thripidae): translocation and persistence in bean plants. Pest Management Science, 62: 759-767.

[54] Tijjani, A., Adebitan, S. A., Gurama, A. U., Haruna, S. G. and Safiya, T. (2014). Effect of some selected plant extracts on Aspergillus flavus, a causal agent of fruit rot disease of tomato (Solanum lycopersicum) in Bauchi State. International Journal of Biosciences ISSN: 2220 6655, Vol. 4, No. 12, p. 244-252.

[55] Tovignan S, Vodoulie SD, Dinhan B. (2001). Cotton pesticides cause more deaths in Benin. Pesticide Newsl. 52:1 2-4.

[56] Williams Q (2005). Control of soil borne pathogens, Bio-integral resource centre (BIRC) Berkeley, California. 215-220. 